Article

\title{
Unusual Components Within a Fine-Grained Contourite Deposit: Significance for Interpretation of Provenance and the Contourite Budget
}

\author{
Shereef Bankole ${ }^{(\mathbb{D}}$, Jim Buckman $* \mathbb{D}$ and Dorrik Stow ${ }^{(\mathbb{D}}$ \\ Institute of GeoEnergy Engineering, EGIS, Heriot-Watt University, Riccarton, Edinburgh EH14 4AS, UK; \\ sb222@hw.ac.uk (S.B.); D.Stow@hw.ac.uk (D.S.) \\ * Correspondence: j.buckman@hw.ac.uk
}

Received: 21 April 2020; Accepted: 25 May 2020; Published: 27 May 2020

\begin{abstract}
Deep-water contourite muds are an important component of many continental margin systems and are currently the focus of much interest amongst deep-water researchers. One outstanding gap in our knowledge of these systems is to understand and quantify a contourite budget, both at the small (facies) scale and at the larger drift scale. A second problem concerns the establishing of robust criteria for discriminating between contourites and associated deepwater facies-turbidites and hemipelagites. This paper contributes to these topics by detailed examination of sediment composition, with a particular focus on potentially diagnostic components, within contourites and hemipelagites from the same depositional basin. Samples were selected from Pliocene to Quaternary muddy contourites from the Gulf of Cadiz (IODP 339) and examined by scanning electron microscopy. The presence of tunicate spicules, micro-bored shell fragments, and a particular species of coccolithophore, Braarudosphaera biglowii, all indicate derivation from shallow waters and hence lateral off-shelf supply. In contrast, micro-mudclasts and fragmented bioclasts are indicative of alongslope transport in bottom currents. A normal planktic component of the contourite muds shows a significant vertical input from pelagic settling. Such diagnostic components can also help in the discrimination between contourites, turbidites and hemipelagites.
\end{abstract}

Keywords: contourite; mudstone; contourite budget; tunicate spicule; SEM

\section{Introduction}

Fine-grained deep-water muds are the dominant sediment type of continental margins, covering large swathes of the outer shelf, slope and rise. Three principal facies groups are recognized-contourites, turbidites and pelagites/hemipelagites-each, to some extent, with its own distinctive characteristics [1,2]. Contourites are a group of closely related deepwater facies deposited under the influence of semi-permanent current action and are commonly referred to as alongslope deposits resulting from semi-continuous depositional processes. This distinguishes them from other deepwater facies that have been deposited either by episodic downslope processes or events (turbidites, debrites, slides, mass-transport deposits and hyperpycnites), or from continuous vertical settling - the so-called background processes (pelagites and hemipelagites) [3-5]. However, because these different processes are part of a process continuum in deepwater, the different facies deposited show some overlap and gradational characteristics, which can make them more difficult to distinguish [6]. A synthesis of the most important criteria for their distinction is provided by Stow and Smillie [2]. 
Whereas recent research has yielded a much improved documentation of bottom-current processes and resultant contourite facies [7-9], there is still a major gap in our understanding of the contourite budget-i.e., where the material for a contourite depositional system comes from and in what relative proportions. Stow et al. [10] outlined the principal sources of sediment supplied to a typical contourite drift to include: (a) vertical flux of siliciclastic material from windblown particles and volcanic dust, river plumes and glaciomarine suspension delivered to the sea surface; (b) vertical flux of biogenic material from sea surface primary productivity, including calcareous and siliceous bioclastic debris, and organic material; (c) slow horizontal advection and vertical settling of mixed siliciclastic and bioclastic material by a combination of hemipelagic processes; (d) episodic downslope flux from low-density turbidity currents and hyperpycnal plumes; (e) intermittent downslope flux via spillover processes, bioturbational and shelf-edge current resuspension; (f) erosion of the seafloor and resuspension by bottom currents adjacent to and upstream from the site of drift deposition. They further summarise the typical and varied composition of contourites and outline a potential sediment budget for the Eirik Drift in the North Atlantic.

The primary aim of this study is to contribute to the discussion of the contourite budget, with specific reference to the Gulf of Cadiz contourite depositional system in the NE Atlantic Ocean, which was drilled and extensively cored during IODP Expedition 339 [11]. This work is not intended as an exhaustive comparative study of all facies types and their composition, but is instead a synthesis of a number of interesting observations made during a larger study into the microstructure of fine-grained deep-water mudstones reported elsewhere $[12,13]$. The secondary aim is to stimulate additional in-depth investigations into the type of particulate materials within deep-water muds of all facies types (turbidites, contourites and pelagites/hemipelagites), their significance in terms of origin, additional environmental information, and their use in differentiating between these different facies; herein we look at contourites and hemipelagites.

\section{Materials and Methods}

A total of 10 samples were selected from cores recovered during IODP Expedition 339, from the Gulf of Cadiz (four sites) and the SW Portuguese margin (one site), ranging in age from Miocene to Quaternary (Figure 1). Based on careful shipboard analysis [11], subsequent work on microfabric $[12,13]$, and further scrutiny during this study, we can identify seven samples from muddy contourites (1386A 5 50-72, 1387B 2H5 67-69, 1387B 2H1 128-130, 1389E 66R1 18-21, 1389E 14R3 27-28, 1390B 2 H4 7-9, 1390B 2H5 94-96), one silty contourite (1387C 48R3 33-35) and two hemipelagites (1387C 56R1 8-10, 1385A 2H6 13-15). Material was prepared as polished thin-sections and examined using a Quanta 650 FEG scanning electron microscope (SEM, Thermo Fischer Scientific, Waltham, MA, USA), operated in low-vacuum mode (0.83 Torr), utilizing backscattered electron (BSE) and gaseous secondary electron (GSE) detectors. Both manual and automated imaging techniques were used. Further details on methods used can be found elsewhere [14,15]. In addition, an Oxford Instruments (Oxford Instruments NanoAnalysis \& Asylum Research, High Wycombe, UK) X-max ${ }^{\mathrm{N}} 150$ mm energy dispersive X-ray (EDX) detector was used to produce elemental maps of the samples. 


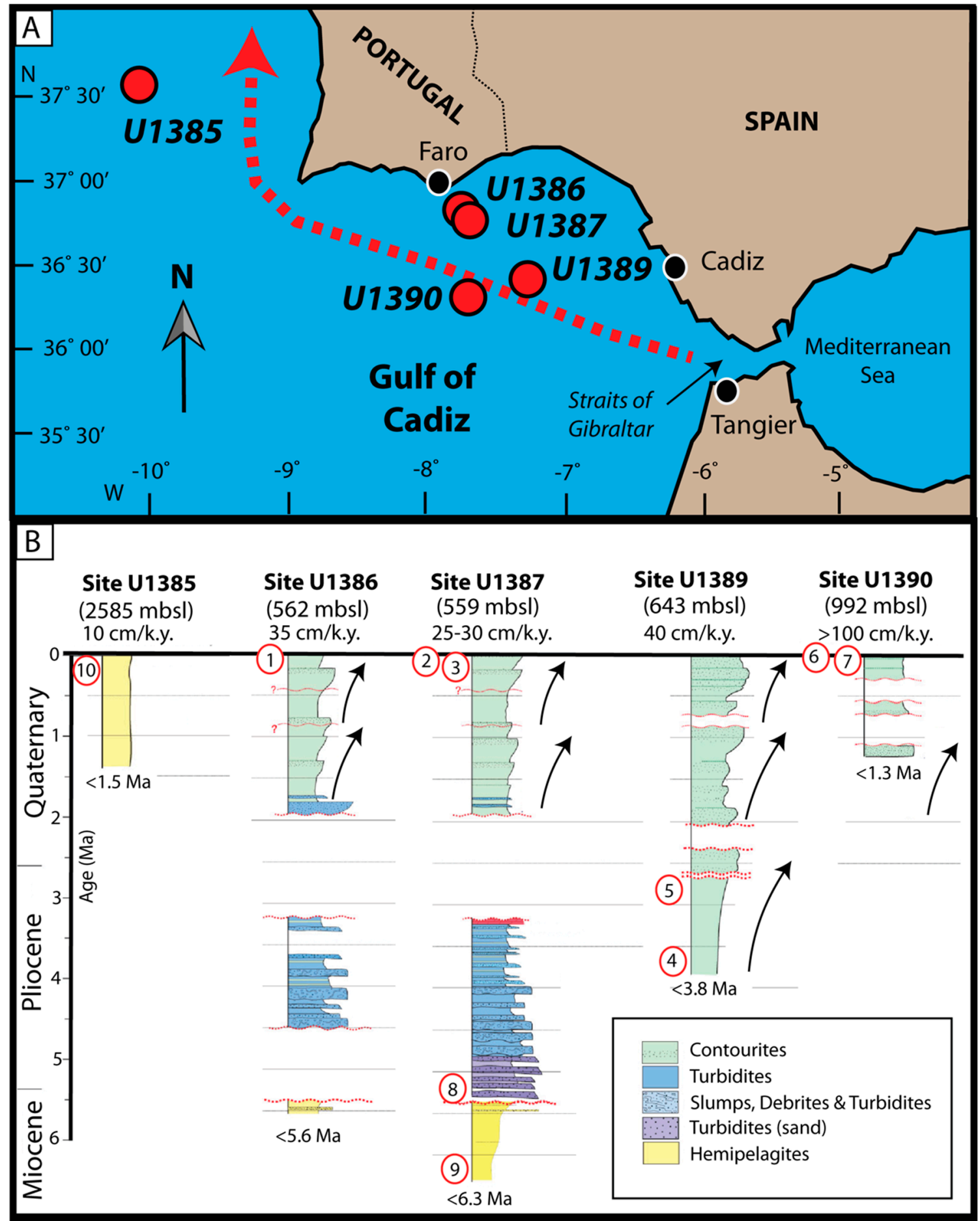

Figure 1. (A) Location map of the sample sites, with indication of the direction of contourite bottom water flow (dashed red arrow). (B) Lithology of sites from IODP 339, with approximate stratigraphic position of samples (1-10) examined in the present study (sample numbers as in Table 1). Note, sample 8 is a silty contourite, identified from cored material, within an otherwise turbidite dominated section. Note, that water depth and sedimentation rates are given below site location data. Based upon http://publications.iodp.org/proceedings/339/EXP_REPT/CHAPTERS/339_101.PDF. 
Table 1. Distribution of particulates within the mudstones studied, noting silt, mica, micro-mudclasts, coccolithophores, foraminifera/calcispheres, tunicate spicules and micro-borings. Samples 1-10: Contourites \#1 = 1386A 5 50-72, \#2 = 1387B 2H5 67-69, \#3 = 1387B 2H1 128-130, \#4 = 1389E 66R1 18-21, \#5 = 1389E 14R3 27-28 (black mud), \#6 = 139B 2H4 7-9 (laminated), \#7 = 1390B 2H5 94-96 (laminated); Silty contourite \#8 = 1387C 48R3 33-35; Hemipelagites \#9 = 1387C 56R1 8-10, $\# 10=1385 \mathrm{~A} 2 \mathrm{H} 6$ 13-15. Key: $\mathrm{Y}=$ present, $\mathrm{YY}=$ very common, $\mathrm{VM}=$ very minor. ${ }^{*}$ includes sand sized particles. ${ }^{\S}$ Large number in part due to larger area examined, and amount of time taken. Green = muddy-silty contourites, yellow = hemipelagite. $?$ denotes uncertainty in generic assignment.

\begin{tabular}{|c|c|c|c|c|c|c|c|c|c|c|}
\hline \multirow[b]{2}{*}{ Sample } & \multirow[b]{2}{*}{ Silty } & \multirow[b]{2}{*}{ Micaceous } & \multicolumn{4}{|c|}{ Coccolithophores } & \multirow[b]{2}{*}{ Foraminifera/Calcispheres } & \multirow[b]{2}{*}{ Tunicate Spicules } & \multirow[b]{2}{*}{ Micro-Mudclasts } & \multirow[b]{2}{*}{ Micro-Borings } \\
\hline & & & "Standard" & $\begin{array}{c}\text { Braarudosphaera } \\
\text { Biglowii }\end{array}$ & Discoaster & ?Pontosphaera & & & & \\
\hline$\# 1$ & $\mathrm{Y}$ & Y & $\mathrm{Y}$ & $\mathrm{Y}$ & - & - & $\mathrm{Y}$ & 15 & $\mathrm{Y}$ & Y \\
\hline$\# 2$ & $\mathrm{Y}$ & $\mathrm{Y}$ & $\mathrm{Y}$ & - & - & - & $\mathrm{Y}$ & 5 & $\mathrm{Y}$ & $\mathrm{Y}$ \\
\hline$\# 3$ & $\mathrm{Y}$ & $\mathrm{Y}$ & $\mathrm{Y}$ & - & - & - & $\mathrm{Y}$ & 1 & Y & Y \\
\hline$\# 4$ & $Y$ & $\mathrm{Y}$ & Y & - & - & - & $\mathrm{Y}$ & 4 & $\mathrm{Y}$ & Y \\
\hline$\# 5$ & $Y$ & $\mathrm{Y}$ & $\mathrm{Y}$ & - & - & - & $\mathrm{Y}$ & 1 & $\mathrm{Y}$ & $\mathrm{Y}$ \\
\hline$\# 6$ & Y & $\mathrm{Y}$ & $\mathrm{Y}$ & $\mathrm{Y}$ & - & - & Low & 10 & $\mathrm{Y}$ & $\mathrm{Y}$ \\
\hline$\# 7$ & $Y Y$ & $\mathrm{Y}$ & $\mathrm{Y}$ & - & - & - & Low & $67 \S$ & $\mathrm{Y}$ & 43 \\
\hline$\# 8$ & $Y^{*}$ & VM & $Y$ & $Y$ & $Y$ & $Y$ & $\mathrm{Y}$ & - & $\mathrm{VM}$ & - \\
\hline$\# 9$ & $\mathrm{Y}$ & $\mathrm{VM}$ & $\mathrm{Y}$ & - & $\mathrm{Y}$ & $\mathrm{Y}$ & $\mathrm{Y}$ & - & VM & - \\
\hline$\# 10$ & $\mathrm{Y}$ & VM & $\mathrm{Y}$ & $\mathrm{Y}$ & VM & - & $\mathrm{Y}$ & - & $\mathrm{VM}$ & 3 \\
\hline
\end{tabular}




\section{Results}

\subsection{Contourites, General Characteristics}

All of the examined (contourite) samples are of fine-grained contourite muds with moderate bioturbation throughout, which accumulated at average rates of sedimentation of $25-35 \mathrm{~cm} \mathrm{ka}^{-1}$ (Figure 1). Most have no visible sedimentary structures, although two samples (1390B 2H4 7-9, 1390B 2H5 94-96) show the preservation of discontinuous silt laminae, within a succession having a much higher rate of sedimentation $\left(\sim 100 \mathrm{~cm} \mathrm{ka}^{-1}\right)$ (Figure 1). Previous textural study shows that they are all classified as silty clays to clayey silts [12], with a minor sand-sized detrital component present in the silty contourite sample (1387C 48R3 33-35). The general appearance is one of a chaotic microfabric (Figure 2), although detailed analyses by Bankole et al. [13] have demonstrated a mixed microfabric is typical of the Cadiz contourites in general, including semi-random, random and parallel-oriented microfabrics.
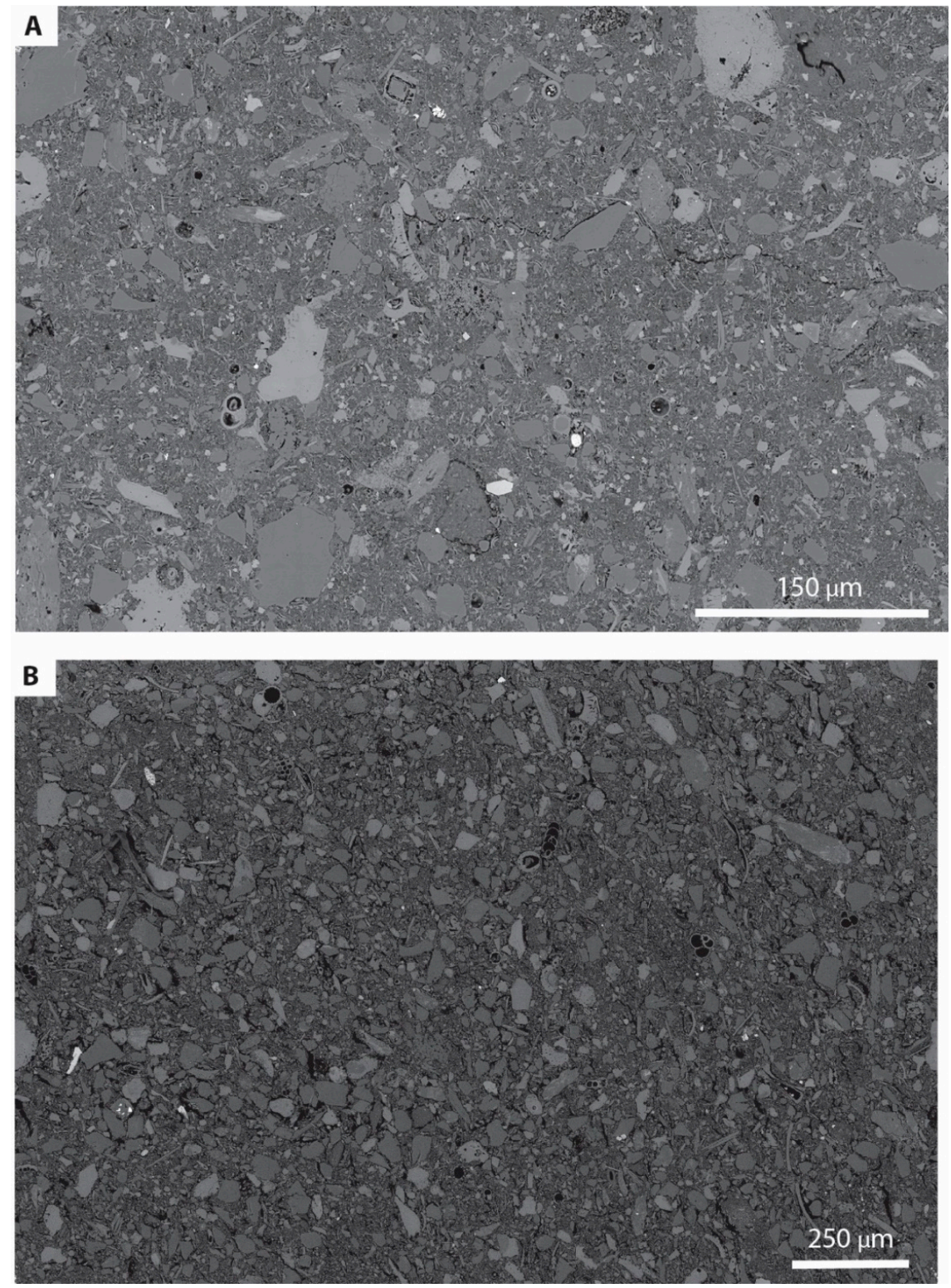

Figure 2. Backscattered (BSE) montages illustrating typical contourite fabric. (A) Sample \#4 Pliocene. (B) Sample \#7 Quaternary. Note that both are silty mudstones, with a sandy component. 
Compositionally, these are mixed bioclastic-siliciclastic contourites. Carbonate content ranges from $18-45 \%$ comprising both biogenic and detrital calcite [6]. Bio-calcite occurs in the form of whole and disarticulated coccolithophores, whole and fragmentary calcispheres, planktic and benthic foraminifera, tunicate spicules, and micro-bored shell fragments. In addition, a small amount of authigenic dolomite is also present. Siliciclastic material is largely clay-sized, with approximately $10 \%$ detrital silt-sized quartz, mica, feldspar, micro-mudclasts, and minor sand-sized components. According to Alonso et al. [6], the clay fraction comprises illite (20-39\%), smectite (18-33\%) and kaolinite (20-30\%). Typical examples and components are illustrated in Figures 3-6.
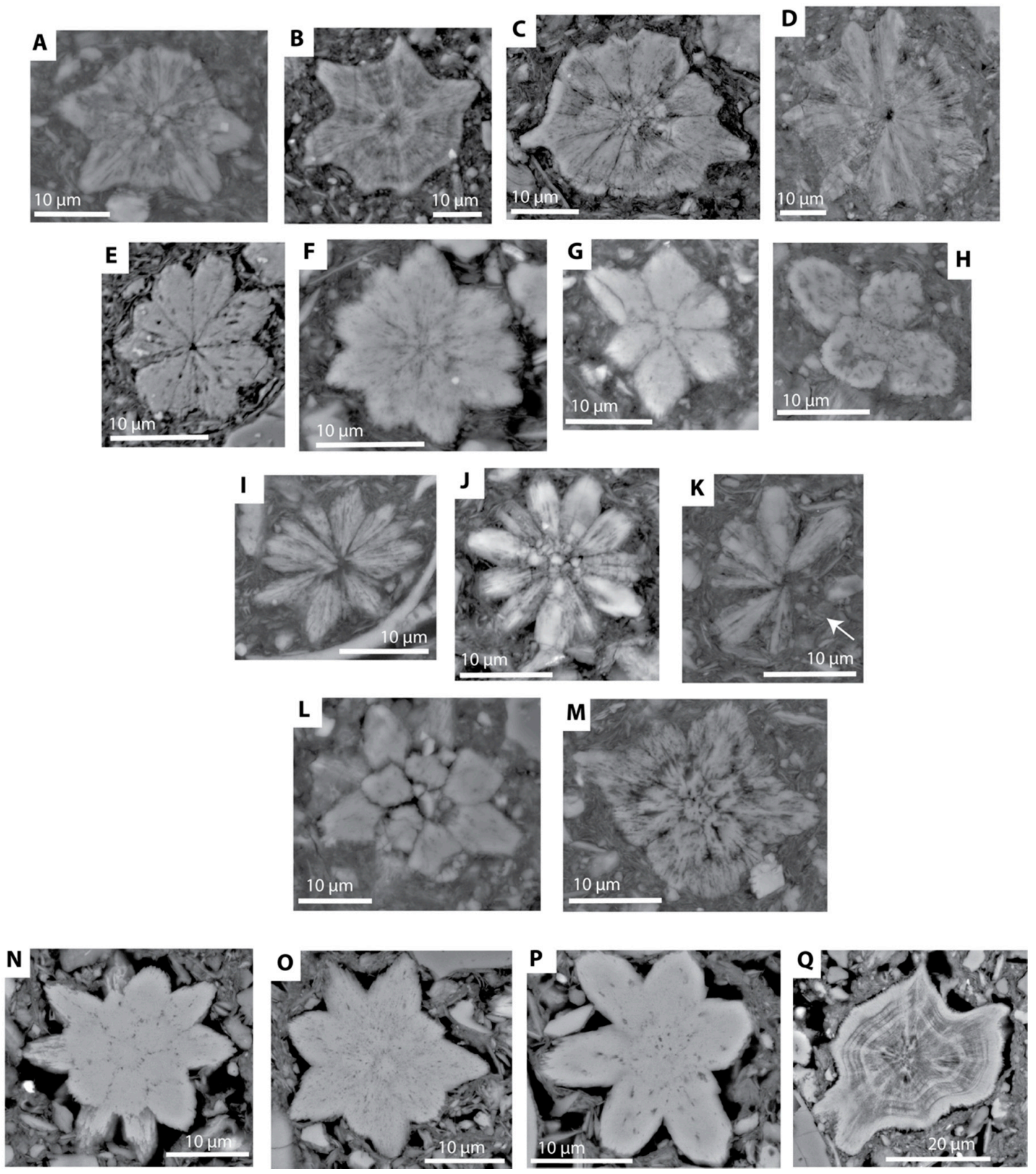

Figure 3. Backscattered electron (BSE) images of typical examples of tunicate spicules from the contourites, (A-M) Sample 1386A 5 50-72 (muddy contourite), (N-Q) Sample 1390B2H5 94-96 (silty contourite), illustrating the wide range of morphologies. $(\mathbf{B}, \mathbf{Q})$ with strongly developed concentric growth lines, and in (B) well-developed radial sectors (dark and light). (K) shows signs of damage due to transportation (missing rays indicated by arrow). 

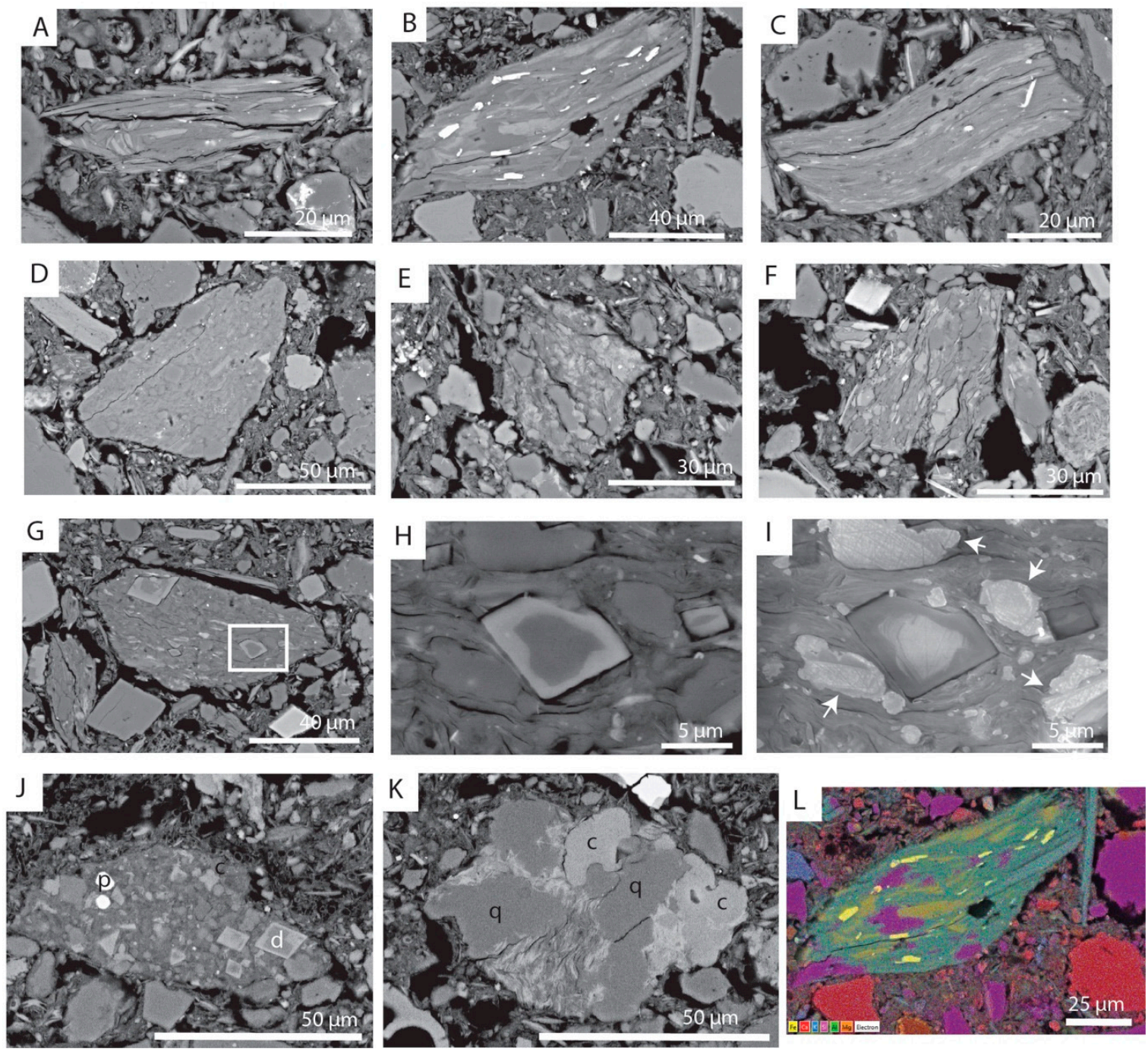

Figure 4. Typical range of micro-mudclasts observed from muddy and silty contourite samples. $(\mathbf{A}-\mathbf{H}, \mathbf{J}, \mathbf{K})$ backscattered electron (BSE) images, (I) gaseous secondary electron (GSE) image, and (L) energy dispersive X-ray (EDX) elemental map. (A-C) typical elongate micro-mudclasts, with evidence of plastic deformation during compaction in (C). (D-F) More equigranular micro-mudclasts. (G) micro-mudclast with quartz silt-sized particles and rhombic authigenic dolomite crystals. (H) Enlarged area from white box in (G), showing detail of dolomite zoning, and in (I) charge contrast image illustrating additional detail of dolomite zoning, and quartz overgrowths around detrital quartz grains (arrows). Sample therefore relatively lithified compared to (C). (J) Micro-mudclast with dolomite (d), pyrite (p), carbonate bio-clasts (c). (K) Siltstone micro-mudclast, with quartz (q) and carbonate bio-clasts (c). (L) Same micro-mudclast as in (B) relatively enriched in $\mathrm{K}$, Fe and $\mathrm{Mg}$ compared to enclosing matrix, indicating that micro-mudclast is not sourced from the same bed.

There are four more "unusual" components present in the samples analysed, including tunicate spicules, micro-mudstone clasts, the coccolithophore Braarudosphaera biglowii, and micro-bored shell fragments. These are described here further.

\subsubsection{Tunicate Spicules}

Spicules of these primitive invertebrate chordates are present in variable amounts within the muddy contourite thin sections examined, with three out of eight having at least 10 tunicate spicules each (Table 1). They are calcareous stellate forms, and highly variable in morphology (Figure 3), with 
between 4 and 12 rays per spicule. Rays can be equal length, or variable in length, and some show apparent indications of abrasion, to the extent that a number of samples are broken in half, or have rays missing (Figure $3 \mathrm{~K}$ ). Individual rays comprise an acicular fabric, some examples show intricate "growth-rings" (Figure 3Q), and in some cases compositional segmentation (Figure 3B).

\subsubsection{Micro-Mudstone Clasts}

These are commonly observed within all the muddy contourites. The majority of micro-mudstone clasts are in the upper range of silt sized $(\sim 50 \mu \mathrm{m})$, elongate to equigranular in shape, and angular to subrounded (Figure 4). Although many micro-clasts are approximately parallel to bedding, some are perpendicular or at variable angles to bedding. They contain variable amounts of silty particles (quartz), mica, dolomite and calcareous micro-organisms (Figure 4J,K).
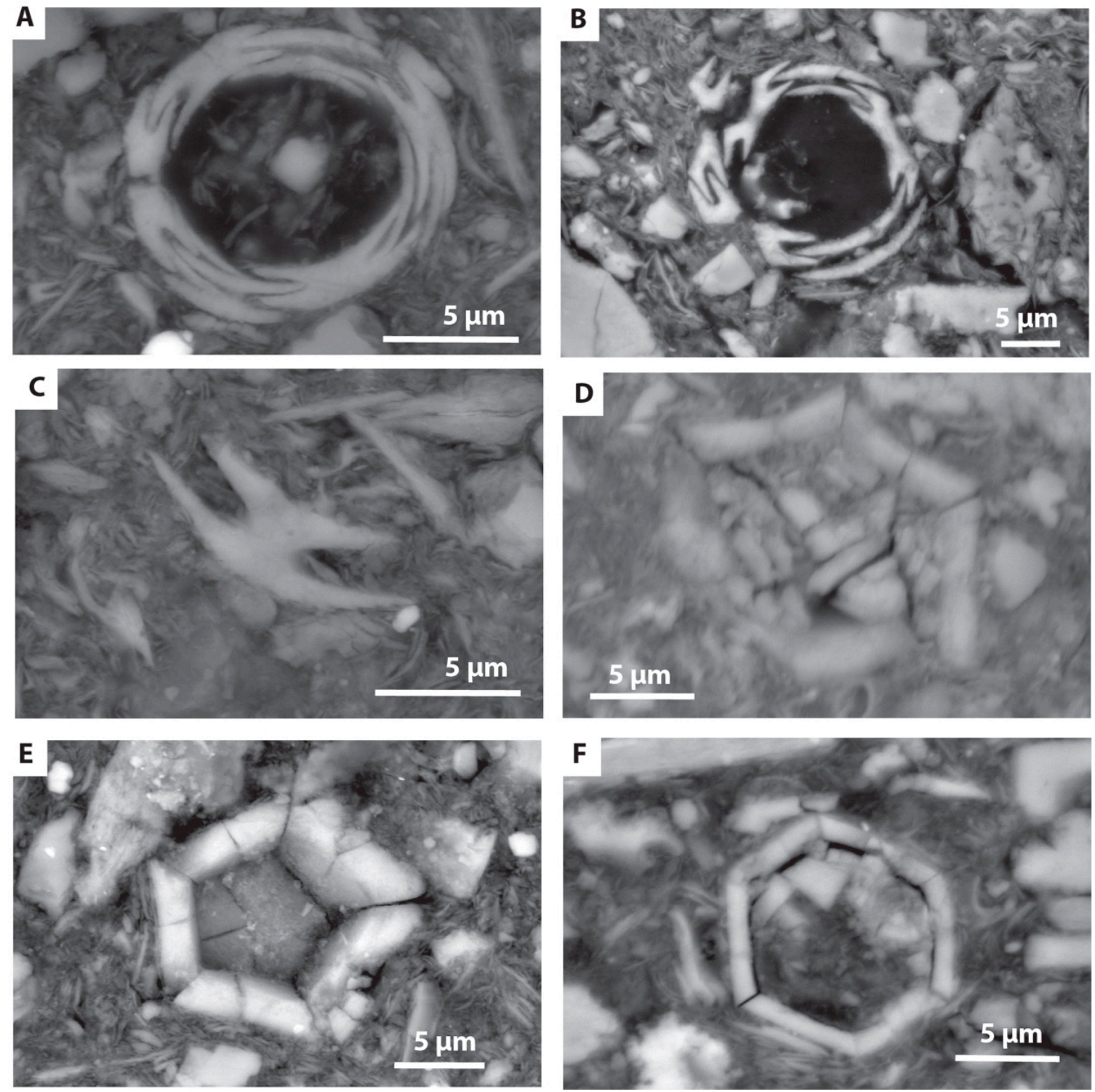

Figure 5. Examples of coccolithphore morphologies from contourites. (A,B) "standard" coccolithphores, (C) individual isolated coccolith plates. (D-F) Braarudosphaera biglowii. 

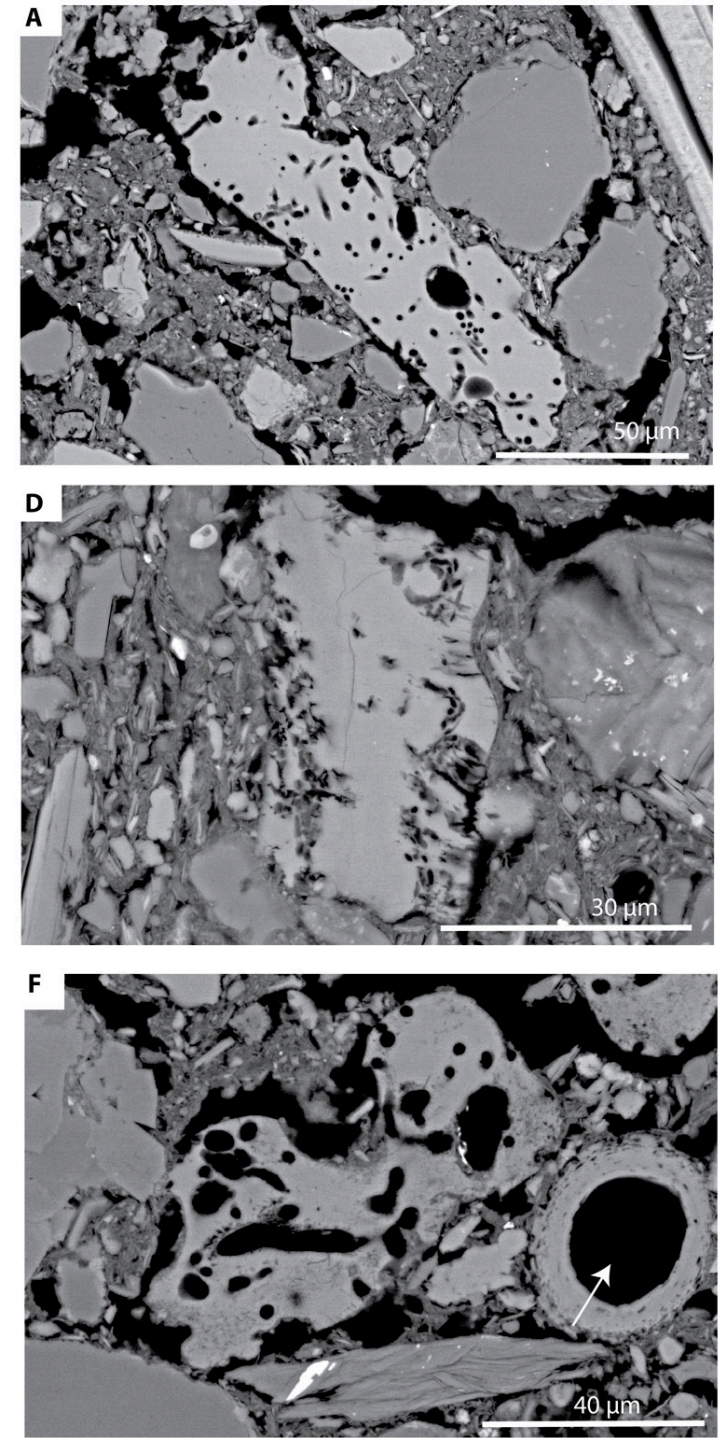
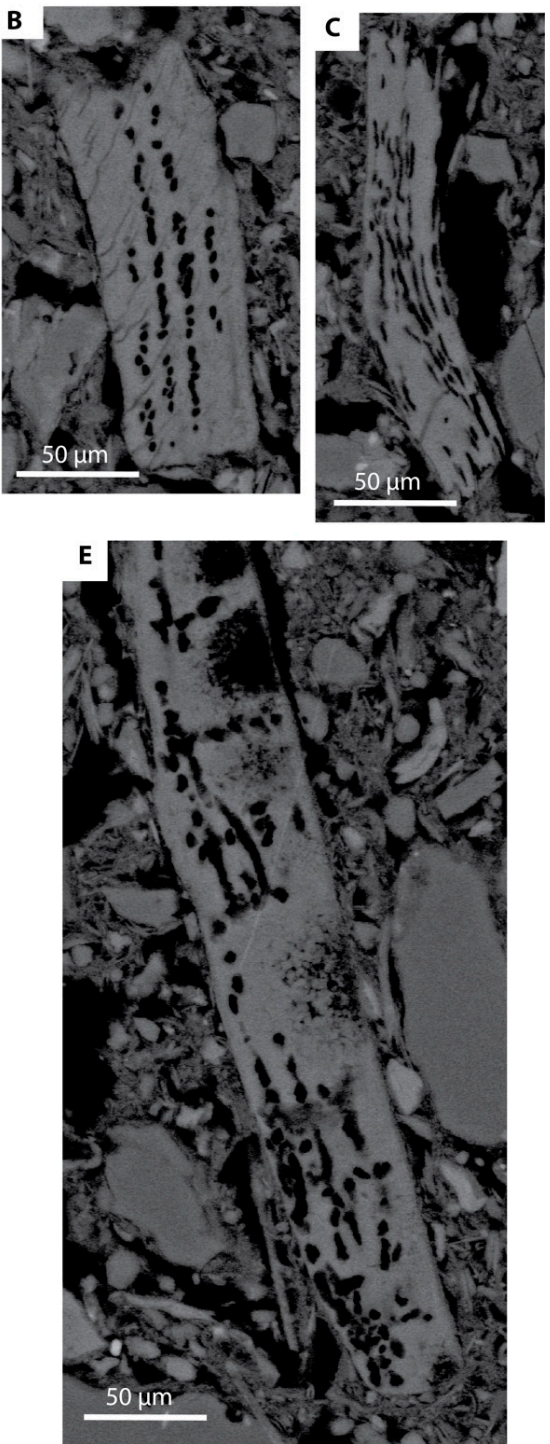

Figure 6. Examples of micro-borings in shelly substrates from contourites. (A,F) two sizes of variably oriented micro-borings. Note, large black structure arrowed in (F) is not a boring. (B,C,E) predominantly horizontal micro-borings, parallel to shell surface, and consistent in size. (D) Mixture of vertical and horizontal micro-borings, of the same size, and concentrated towards the internal and external shell surfaces.

\subsubsection{Coccolithophores (Braarudosphaera biglowii)}

The "standard" range of coccolithophores, as described by Balestra et al. [16] and in the shipboard results [11], including Emiliana huxleyi and Gephyrocapsa caribbeanica, are common within all the muddy contourites examined (Figure 5A-C), whereas Braarudosphaera biglowii occurs within two of the muddy contourites (Table 1), and then only rarely. Braarudosphaera biglowii has a very distinctive morphology, comprising robust pentameral plates (nanoliths) that can be seen to be further subdivided into five (Figure 5D,E). The overall width is $\sim 15 \mu \mathrm{m}$, with individual plates $\sim 5 \mu \mathrm{m}$.

\subsubsection{Micro-Bored Shells}

Micro-bored shells/tests are not straightforward to identify, being easily confused with microporous (recrystallized) calcite. However, clear samples are commonly observed in all of the examined muddy contourite samples (Figure 6), with 43 identified from three methodically scanned areas (sample 1390B 2H5 94-96, laminated contourite). Micro-borings occur in broken often highly 
fragmentary shelly materials, and have a variety of distinctive different forms, with both vertical and horizontal elements, but with horizontal apparently dominant, as well as a variety of sizes (Figure 6). As such the observed micro-borings are likely to have had a range of constructors.

\subsection{Silty Contourite}

The silty contourite is similar in its bioturbation, composition and fabric to that of the finer-grained muddy contourites (above), although it is stratigraphically older-early Pliocene. The principal differences are the presence of coarser sandy detrital grains, and larger foraminifera (Figure 7a). In addition, the sample contains abundant examples of Discoaster coccolithophores (Figure 8), some minor Braarudosphaera biglowii and one ?Pontosphaera spp.
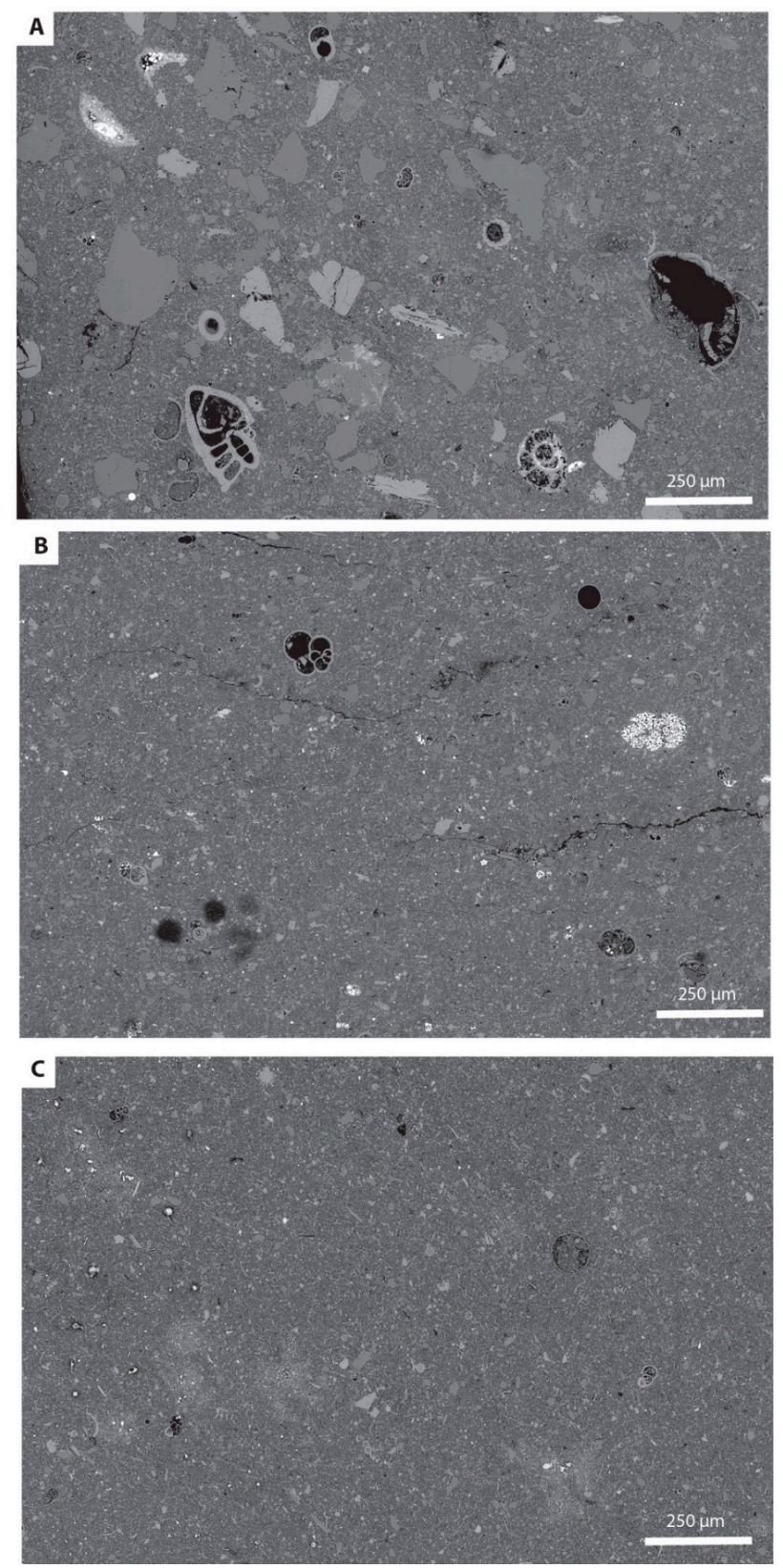

Figure 7. Backscattered electron (BSE) montages of (A) silty contourite and (B,C) two hemipelagite samples examined in the present study (1387C 56R1 8-10 and 1385A 2H6 13-15 respectively). Illustrating similarities and differences. (A) Contains large sand-sized detrital particle, fragmentary bio-carbonate grains and large foraminifera, (B) silty, (C) silty with burrows. 

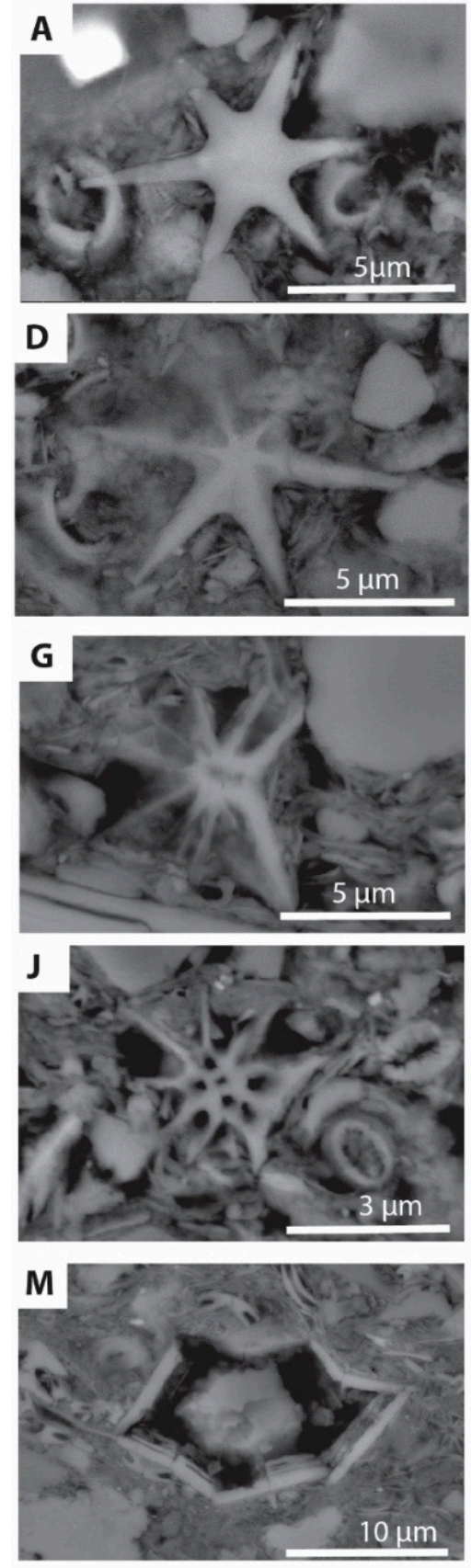
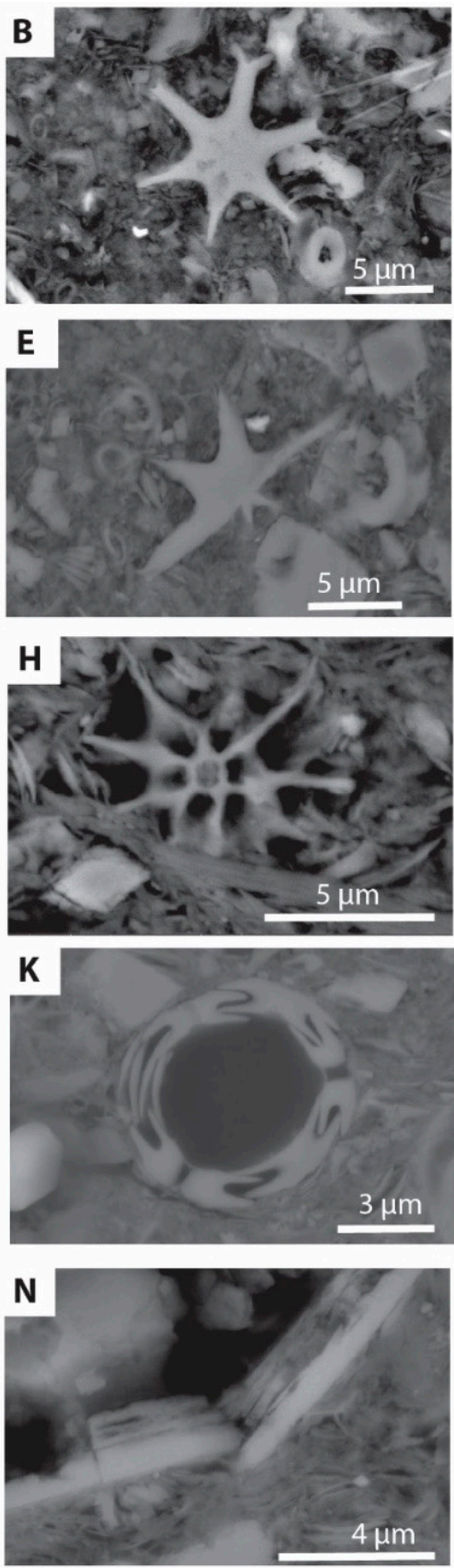
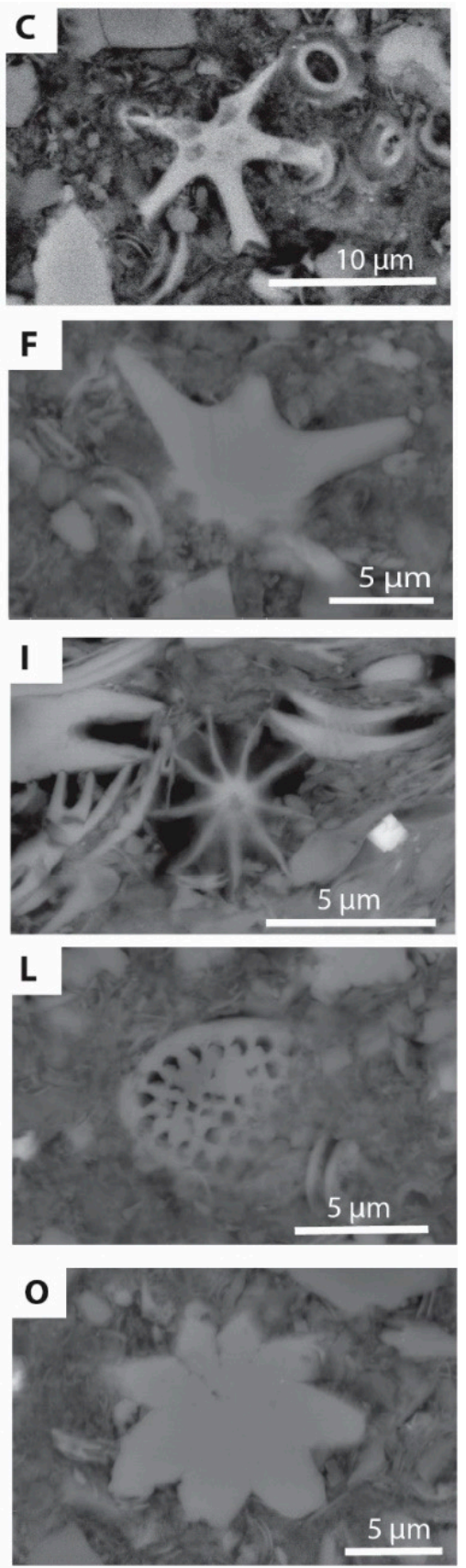

Figure 8. Backscattered electron (BSE), scanning electron microscope (SEM), of coccolithophores from silty contourite sample 1387C 48R3 33-35. (A-J) Discoaster, with (A-D) plan views, showing six rayed "star-like" morphology, (E,F) cross-sections, illustrating small radial structures on the upper surface of Discoaster, $(\mathbf{G}, \mathbf{J})$ transverse sections through upper surface structures, and $(\mathbf{H}, \mathbf{I})$ plan views of same. (K) "standard" coccolithophore structure, displaying interlocking plates (single plates also seen in (I)). (L) ?Pontosphaera. $(\mathbf{M}, \mathbf{N})$ Braarudosphaera biglowii. (O) Radial calcitic bio-structures similar to tunicate spicules, but comprising plates rather than fibrous structure. Possible form of Discoaster. 


\subsection{Hemipelagites}

In general, the two hemipelagite samples are finer grained than the contourites, i.e., more clay-rich than silt-rich, with less obvious micaceous material, and a greater carbonate content $(>60 \%)$. They show extensive and varied bioturbation and burrowing throughout, and a completely random microfabric. The high amount of biogenic calcareous material includes a variety of coccolithophores (whole and disassociated), planktic and benthic foraminifera (Figure 7B,C). In addition, the Miocene sample contains abundant Discoaster (Figure 9), and three ?Pontosphaera, whereas the Quaternary specimen contains limited numbers of Discoaster (Figure 10), and one example of Braarudosphaera biglowii. Some small micro-clasts and limited numbers of micro-bored shelly material (Figure 10), as well as detrital quartz filled and pyrite burrows (Figures $7 \mathrm{C}$ and 10) are present. There are no definitive tunicate spicules.
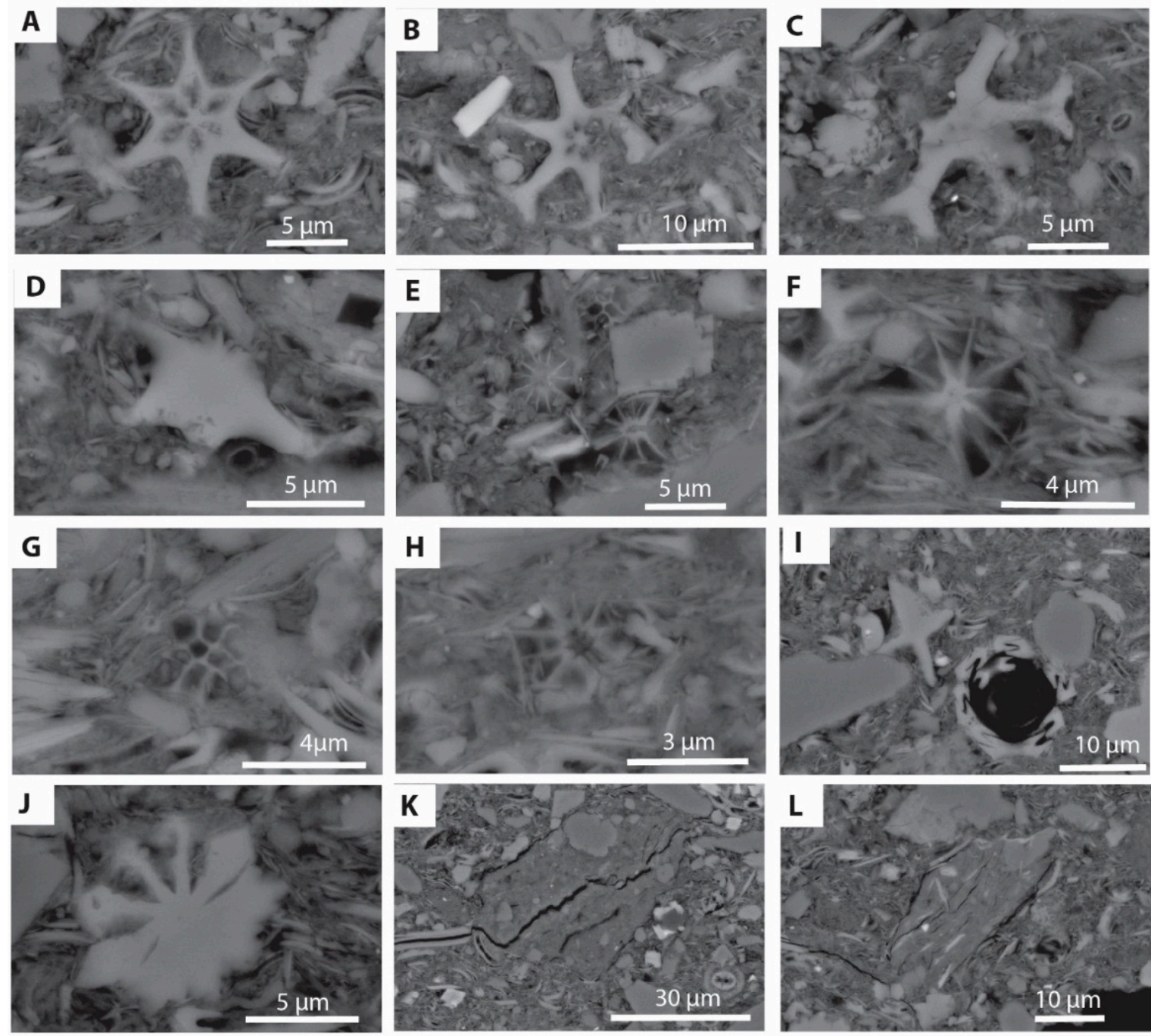

Figure 9. Backscattered electron (BSE), scanning electron microscope (SEM) images from hemipelagite 1387C 56R1, from the Miocene. (A-D) Large form of Discoaster. (E-H) "Small form" of Discoaster = upper part of larger specimens. (I) X-shaped bio-carbonate (?coccolithophore), and "standard" whole coccolithophore, with interlocking plates. (J) Unusual form of coccolithophore, comprising radial plates. $(\mathbf{K}, \mathbf{L})$ micro-mudclasts, with quartz and mica. 

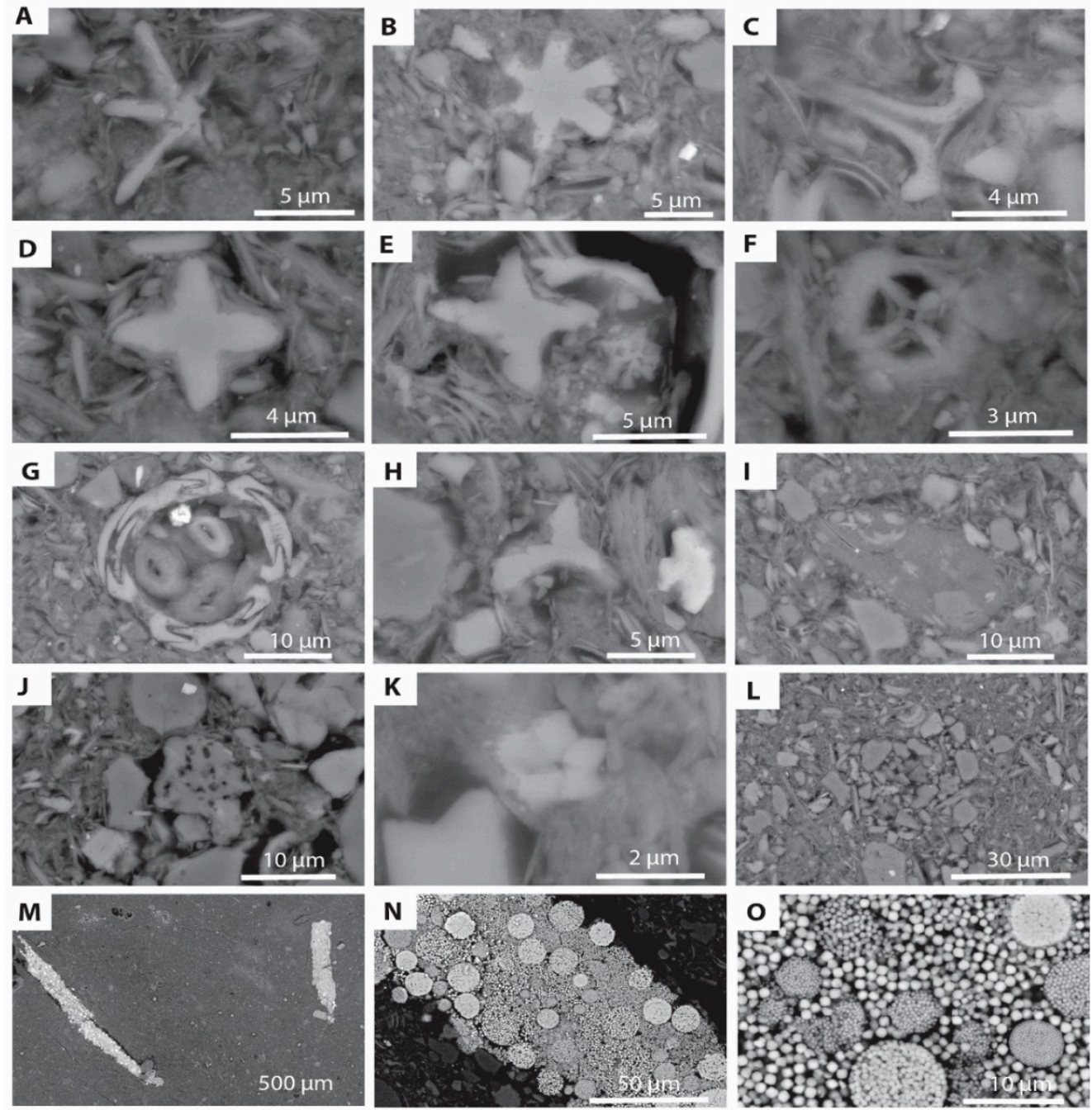

Figure 10. Backscattered electron (BSE), scanning electron microscope (SEM) images from hemipelagite 1385A 2H6 13-15, from the Quaternary. (A,B) Examples of Discoaster. (C) trumpet shaped coccolithophore plate. (D,E) X-shaped bio-carbonate plates (?coccolithophore). (F) Similar to $(\mathbf{D}, \mathbf{E})$ but with the addition of an outer circular ring. $(\mathrm{G})$ "Standard" whole coccolithophore, with typical interlocking plates. (H) Y-shaped bio-carbonate fragment. (I) Micro-mudclast, containing coccolithophore plates. (J) Small (rare) micro-bored carbonate particle. (K) Bioclast, similar to tunicate spicules, but comprising calcite plates rather than fibres (?coccolithophore). (L) Silt grains concentrated within horizontal burrow (centre of image). (M-O) Pyrite filled burrows (Trichichnus).

\section{Discussion}

\subsection{Environmental and Source Significance of "Unusual" Components}

\subsubsection{Tunicate Spicules}

The occurrence of tunicate spicules may well be of significance in terms of environmental interpretation. According to the British Columbia tunicate key [17], stellate calcareous tunicate spicules occur in species of Didemnum and Trididemenum, and are abundant in rocky shallow-water environments, from intertidal to $400 \mathrm{~m}$ depth. Other workers have illustrated didemnid ascidian spicules on hard substrates commonly from shallow water $(0-50 \mathrm{~m})$, with some deeper-water (1500 m) [18]. Wei [19] records tunicate spicules mainly from less than $400 \mathrm{~m}$, and more rarely down to $900 \mathrm{~m}$, where redistribution downslope is associated with turbidites. 
It seems most likely, therefore, that the tunicate spicules recorded from the contourites herein originated from shallow-shelf waters, from the colonisation of rocky substrates (or larger shelly material) [17]. Their broken up remains were then transported into deeper water by turbidity currents, slope spillover or other mass flow processes, and subsequently reworked by bottom currents flowing parallel to the continental slope. The present-day water depths for the contourite sites sampled range from $559 \mathrm{~m}$ to $992 \mathrm{~m}$, and the highest count (sample 7) is from site 1390 in $992 \mathrm{~m}$ water depth. This further supports an off-shelf supply, although an in situ origin for the tunicate spicules cannot be totally excluded. Transportation, or at least a degree of reworking and winnowing, of the tunicate spicules is indicated by the broken and abraded nature of some of the samples (Figure 3K).

\subsubsection{Coccolithophores}

The coccolithophore assemblage at all sites is dominated by the "standard" species found in this region and in the time intervals sampled, and clearly represents an abundant supply of pelagic material to the contourite sediments, by vertical settling coupled with alongslope transport in bottom currents. However, the presence of the distinctive coccolithophore species Braarudosphaera biglowii may indicate an additional source. Konno et al. [20] have noted that this species shows a preference for low-salinity nutrient-rich coastal water, often associated with algal blooms. This is also confirmed by other authors [21].

This suggests that those samples recorded from the contourites herein, most likely originated from shallow-water sediments. Although the tests of Braarudosphaera biglowii appear thick and robust, the plates are held together by an organic frame, and as such would be unlikely to fair well if transported over large distances (pers comm. A. Poulton 2019). Given the apparently intact nature of the Braarudosphaera biglowii species observed, and their low occurrence, these could be interpreted as taphonomic survivors of short mass flow transport from shallower waters, or as offshore dispersal of coastal pelagic blooms via wind and near-shore currents. The numbers and distribution currently noted are not enough to resolve this question, although it is flagged here as worthy of further investigation.

Other substantially whole coccolithophores (Figure 5A,B and Figure 8K) and foraminifera (Figure 7A) clearly represent pelagic input into the contourite drift. While disarticulated coccolithophores (Figure 2A,B and Figures 5C and 8I) and broken foraminifera (Figure 2A,B), strongly indicate current reworking (winnowing), possible heavy alteration through bioturbation, or a combination of both. Although many other species of coccolithophore observed during the current study are apparently intact (Figure 5A,B and Figure 8K), the strongly interlocking nature of the coccoliths make these more robust than Braarudosphaera biglowii, and their occurrence does not therefore discount either winnowing or bioturbation.

\subsubsection{Micro-Boring}

Micro-borings of shelly fragments can be the product of a range of micro-organisms, but are commonly formed by endolithic cyanobacteria, red and green algae and fungi [22,23]. In general, many micro-borings that are predominantly orientated perpendicular to the substrate are considered likely to be the product of photosynthetic organisms (such as algae), whereas more horizontally orientated ones may result from fungal (non-photosynthetic) activity [22]. Microboring orientation has therefore been taken as an indicator of palaeo water-depth, or more literally as the position of the photic zone $[22,24,25]$. Although, in reality this is an over simplification, the small number of observed samples herein illustrate both horizontal and vertical components (Figure 6), making any clear interpretation of their environmental significance difficult. High-levels of micro-boring, could be taken as an indicator of multiple phases of reworking/winnowing due to strong bottom currents, or through storm activity in shallow waters, with subsequent relocation to deeper water by mass flow transportation. Future work into this area is clearly necessary, and likely to be informative for environmental and process studies. 


\subsubsection{Micro-Clasts}

Mudstone and siltstone micro-clasts are relatively common within the contourite deposits studied here, and have recently become of great interest in sedimentological studies, associated with both turbidite and contourite deposits [26,27].

The shape and zonation of dolomite within some of the micro-mudclasts (Figure 4G-J) clearly indicate an authigenic origin, as does micro-quartz growth on quartz silt grains within the clasts. In both cases, the latter implies that the micro-mudclasts have undergone a degree of lithification, although at least some clasts were soft enough to have undergone deformation during compaction (Figure 4C). Energy dispersive X-ray (EDX) mapping of mudclasts illustrates that compositionally the clasts are higher in $\mathrm{K}, \mathrm{Fe}$ and $\mathrm{Mg}$, compared to the enclosing matrix (Figure $4 \mathrm{~L}$ ), indicating that the micro-clasts are not from the same source as the background contourite matrix material. All indications suggest that the majority of micro-mudclasts derive from at least a partially lithified source and, therefore, are likely to have been transported some distance before deposition and incorporation within the muddy contourites.

\subsection{Facies Discrimination}

Discrimination between the principal deepwater facies-hemipelagites, contourites and turbidites—can be fraught with difficulty, especially where the deposits are all fine-grained [2]. Different criteria have been applied in various studies, including primary sedimentary structures, bioturbation, textures and microfabric [10,28]. Textural discrimination [29] and microfabric discrimination [30] have been further developed in recent $\mathrm{PhD}$ theses by these authors. Alonso et al. [6] applied a combination of attributes to the mixed deepwater facies of the Gulf of Cadiz.

This study has drawn attention to the use of "unusual" components for elucidating potential source areas and hence likely depositional processes. Although the sample numbers used are insufficient to be definitive, there are some notable differences between the examined muddy contourites and hemipelagites. In particular, tunicate spicules, micro-borings and micro-mudclasts appear to be relatively common in the contourites but generally absent to rare in the hemipelagites. Furthermore, the environmentally sensitive coccolithophore Braarudosphaera biglowii is more common in contourites than hemipelagites, although the evidence is not definitive. Some of these components noted are most likely to have been derived from shallow water (shoreline to shelf depths) and would therefore be still more abundant in turbidites. Confirmation of this proposition awaits further study. We would further suggest that these criteria can be applied elsewhere (other geographies and time periods).

\subsection{Contourite Budget}

A still outstanding question in contourite research is to accurately establish a sediment budget for any particular contourite drift or system. The only attempt at quantifying such a budget was for the Eirik Drift, although this was simply a preliminary estimate [10]. The data presented here is quite insufficient on its own to make a similar estimate for either the Faro Drift or the entire Cadiz Contourite Depositional System, but we can make some pertinent observations as follows:

1. The presence of tunicate spicules, micro-borings and the coccolithophore Braarudosphaera biglowii in the Cadiz contourites all suggest an origin in shallow nearshore to shelf waters. This implies that an important part of the contourite budget was derived laterally, via turbidity currents or other off-shelf supply process.

2. The presence of micro-mudclasts and generally fragmented bio-clasts indicate probable erosion and transport by alongslope bottom currents as a supply to the contourite drift.

3. The abundance of a normal planktic assemblage of foraminifera and coccolithophores indicates that vertical supply remains a significant part of the contourite budget.

However, if we combine these observations with the more extensive work on composition of turbidites and contourites from the Gulf of Cadiz by Alonso et al. [6], then we can propose an 
initial budget estimate for the Cadiz drift system. Compositional data on contourites (from [6]) show a relatively high carbonate percentage (18-45\%), much of which was of planktonic biogenic origin. A further distinctive component of these contourites is smectite (and inter-layered) clay minerals, almost certainly derived from the Guadalquivir River, re-circulation via the Strait of Gibraltar, and erosion of mud diapirs exposed at the seafloor. These are all well upstream of the drift sites sampled and therefore indicate incorporation into and transport by MOW bottom currents. All the contourites sampled, from a range of different sites spread along the margin, have a well-mixed, uniform composition, which indicates a dominant alongslope supply, rather than varied downslope input locally. Turbidites that are interbedded with contourites near the base of the drift succession (Pliocene age) have a significant proportion of quartz and mica, some heavy minerals and glauconite, less carbonate (mainly land-derived), and little or no smectite clays.

Based on these data, together with our own observations on unusual components, we would infer the Quaternary drift budget to include approximately 30-35\% pelagic biogenics and $65-70 \%$ land-derived material (Figure 11). Of the latter, only about 5\% arrives at the drift sites directly via hemipelagic diffusion from wind-blown and river plume supply, whereas 60-65\% is transported in bottom currents. The downslope supply of tunicate spicules, micro-bored shells and Braarudosphaera biglowii to the bottom current system occurred in an upstream location. The micro-mudclasts were mostly eroded from the seafloor by bottom currents, and some perhaps by turbidity currents, which were then pirated by bottom currents. These also served to fragment bioclasts and homogenise the overall drift composition. Further work to better quantify the distribution of these unusual components, together with that of the bulk components, would help contribute towards establishing a more accurate contourite budget.

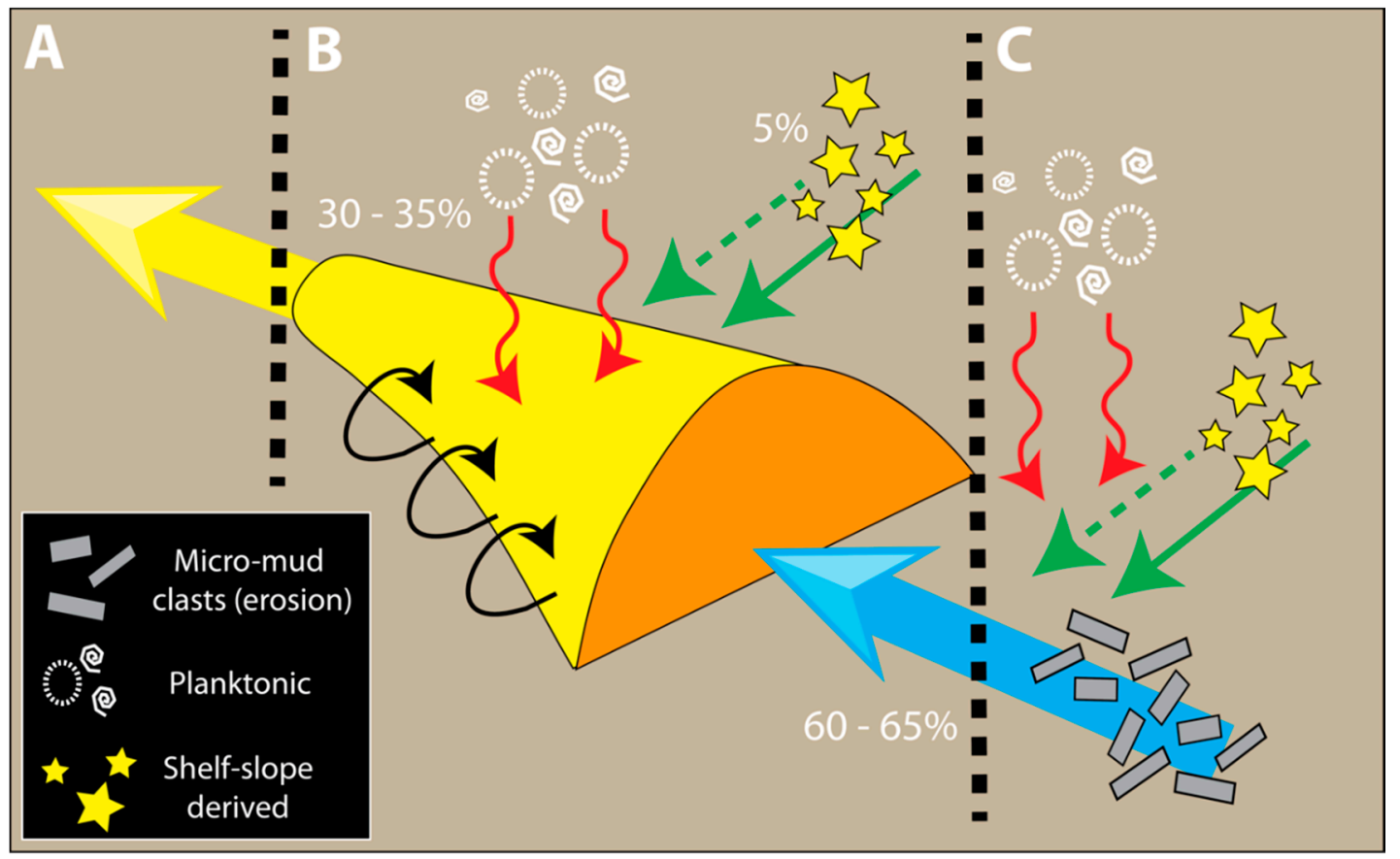

Figure 11. Schematic cartoon, illustrating components of contourite budget. (A) Outflux in bottom currents, (B) Influx for nett drift construction, (C) upstream influx to bottom currents. Red arrows indicate settlement of pelagic material, solid green arrow equals turbidite derived, broken green arrow represents slope spillover, and black arrows local erosion (of the drift) by bottom currents. Large blue arrow largely erosional and transportational processes, leading to influx into drift. Large yellow arrow, outflux from drift area. After Stow et al. [10]. Estimated contourite budget: 30-35\% for vertical settling (planktonic) over the drift, 60-65\% for bottom-current transport (includes downslope and planktonic supply to the bottom current), and $5 \%$ for direct lateral supply near the drift. 


\section{Conclusions}

Detailed analysis of the composition of contourites can yield important information about sediment provenance, and hence provide evidence for establishing a contourite sediment budget. This concept is illustrated by careful study of the fine-grained particulate material from selected IODP 339 sites, with a particular focus on some of the more unusual components in the contourite sediments. Tunicate spicules and micro-bored fragmentary shelly material are both indicative of derivation from shallow water (coastal to shelf). Furthermore, the occurrence of Braarudosphaera biglowii suggests an origin in low-salinity nutrient-rich coastal waters and the common occurrence of algal blooms. Together these components support the importance of lateral material supply to the contourite drift system. However, when combined with other compositional data, they suggest that much of this lateral supply occurred upstream of the drift sites, and was transported as normal load in the bottom currents. The presence of moderately well lithified micro-mudclasts within the muddy contourites demonstrates that such particulates may have travelled considerable distances, from areas where lithified mudstones were exposed and undergoing active erosion. These are associated with fragmentary bioclastic material and therefore indicate the importance of alongslope supply in bottom currents. The presence of planktic foraminifera and coccolithophores indicates the importance of vertical supply to the contourites. We have made a first attempt at a contourite budget for the Cadiz drift system. More detailed work to quantify all components is needed to establish a more accurate contourite budget.

Author Contributions: Conceptualization, J.B.; methodology, J.B., S.B.; formal analysis, J.B., S.B.; investigation, J.B.; resources, J.B.; writing—original draft preparation, J.B.; writing-review and editing, J.B., D.S., S.B.; supervision, J.B., D.S. All authors have read and agreed to the published version of the manuscript.

Funding: No specific funding of this study, although data has been extracted from materials from a PhD, funded by PTDF, Nigeria.

Acknowledgments: The Centre for Environmental Scanning Electron Microscopy (CESEM) is thanked for access and use of scanning electron microscopy and computer facilities. The International Oceanic Drilling Program (IODP) is acknowledged for access to materials.

Conflicts of Interest: The authors declare no conflict of interest.

\section{References}

1. Potter, P.E.; Maynard, J.B.; Pryor, W.A. Sedimentology of Shale: Study Guide and Reference Source; Springer: New York, NY, USA, 2012; p. 310.

2. Stow, D.; Smillie, Z. Distinguishing between Deep-Water Sediment Facies: Turbidites, Contourites and Hemipelagites. Geosciences 2020, 10, 68. [CrossRef]

3. Stow, D.A.; Mayall, M. Deep-water sedimentary systems: New models for the 21st century. Mar. Pet. Geol. 2000, 17, 125-135. [CrossRef]

4. Huneke, H.; Mulder, T. Deep-Sea Sediments; Elsevier: Amsterdam, The Netherlands, 2011.

5. Pickering, K.; Hiscott, R. Deep Marine Systems: Processes, Deposits, Environments, Tectonics and Sedimentation; Wiley \& American Geophysical Union: Washington, DC, USA, 2016.

6. Alonso, B.; Ercilla, G.; Casas, D.; Stow, D.A.; Rodríguez-Tovar, F.J.; Dorador, J.; Hernández-Molina, F.-J. Contourite vs gravity-flow deposits of the Pleistocene Faro Drift (Gulf of Cadiz): Sedimentological and mineralogical approaches. Mar. Geol. 2016, 377, 77-94. [CrossRef]

7. Rebesco, M.; Camerlenghi, A. Contourites; Elsevier: Amsterdam, The Netherlands, 2008; Volume 60, pp. 457-489.

8. Rebesco, M.; Hernández-Molina, F.J.; Van Rooij, D.; Wahlin, A. Contourites and associated sediments controlled by deep-water circulation processes: State-of-the-art and future considerations. Mar. Geol. 2014, 352, 111-154. [CrossRef]

9. Hernández-Molina, F.; Sierro, F.; Llave, E.; Roque, C.; Stow, D.; Williams, T.; Lofi, J.; Van Der Schee, M.; Arnáiz, A.; Ledesma, S. Evolution of the gulf of Cadiz margin and southwest Portugal contourite depositional system: Tectonic, sedimentary and paleoceanographic implications from IODP expedition 339. Mar. Geol. 2016, 377, 7-39. [CrossRef] 
10. Stow, D.A.V.; Hunter, S.; Wilkinson, D.; Hernández-Molina, F.J. The nature of contourite deposition. In Contourites; Rebesco, M., Camerlenghi, A., Eds.; Elsevier: Amsterdam, The Netherlands, 2008; Volume 60, pp. 143-156.

11. Stow, D.; Hernández-Molina, F.; Llave, E.; Bruno, M.; García, M.; Del Río, V.D.; Somoza, L.; Brackenridge, R. The Cadiz Contourite Channel: Sandy contourites, bedforms and dynamic current interaction. Mar. Geol. 2013, 343, 99-114. [CrossRef]

12. Bankole, S.A.; Buckman, J.; Stow, D.; Lever, H. Grain-size analysis of mudrocks: A new semi-automated method from SEM images. J. Pet. Sci. Eng. 2019, 174, 244-256. [CrossRef]

13. Bankole, S.A.; Buckman, J.; Stow, D.; Lever, H. Automated Image Analysis of Mud and Mudrock Microstructure and Characteristics of Hemipelagic Sediments: IODP Expedition 339. J. Earth Sci. 2019, 30, 407-421. [CrossRef]

14. Buckman, J.; Mahoney, C.; Mäerz, C.; Wagner, T.; Blanco, V. Identifying biogenic silica: Mudrock micro-fabric explained through charge contrast imaging. Am. Mineral. 2017, 102, 833-844. [CrossRef]

15. Buckman, J.; Mahoney, C.; Bankole, S.; Couples, G.; Lewis, H.; Wagner, T.; März, C.; Blanco, V.; Stow, D. Workflow model for the digitization of mudrocks. In Application of Analytical Techniques to Petroleum Systems; Dowey, P., Osborne, M., Volk, H., Eds.; Geological Society of London, Special Publications: London, UK, 2018; Volume 484. [CrossRef]

16. Balestra, B.; Flores, J.-A.; Hodell, D.A.; Hernández-Molina, F.J.; Stow, D.A.V. Pleistocene calcareous nannofossil biochronology at IODP Site U1385 (Expedition 339). Glob. Planet. Chang. 2015, 135, 57-65. [CrossRef]

17. Gartner, H. BC Tunicates. 2014. Downloaded from Royal BC Museum Digital Tunicates (November 2019). Available online: http://taxonomy.royalbcmuseum.bc.ca/Taxonomy/viewer/BC_Tunicates.aspx (accessed on 26 May 2020).

18. Varol, O.; Houghton, S.D. A review and classification of fossil didemnid ascidian spicules. J. Micropaleontol. 1996, 15, 135-149. [CrossRef]

19. Wei, W. Abundance patterns of Tunicate spicules of the Great Barrier Reef-Queensland Plateau Transect sites: Implications for downslope transport and Early Pleistocene initiation of the Central Great Barrier Reef. In Proceedings of the Ocean Drilling Program, Scientific Results, College Station, TX, USA; 1993; Volume 133, pp. 447-453.

20. Konno, S.; Harada, N.; Narita, H.; Jordan, R.W. Living Braarudosphaera bigelowii (Gran \& Braarud) Deflandre in the Bering Sea. J. Nannoplankton Res. 2007, 29, 78-87.

21. Kimoto, K.; Xu, X.; Ahagon, N.; Nishizawa, H.; Nakamura, Y. Culturing protocol and maintenance for living calcareous plankton. JAMSTECR 2003, 48, 155-164.

22. Glaub, I. Recent and sub-recent microborings from the upwelling area off Mauritania (West Africa) and their implications for palaeoecology. In The Application of Ichnology to Palaeoenvironmental and Stratigraphic Analysis; McIlroy, D., Ed.; Geological Society of London, Special Publications: London, UK, 2004; pp. 63-77.

23. Wisshak, M.; Seuß, B.; Nützel, A. Evolutionary implications of an exceptionally preserved Carboniferous microboring assemblage in the Buckhorn Asphalt lagerstätte (Oklahoma, USA). In Current Developments in Bioerosion; Erlangen Earth Conference Series; Springer-Verlag: Berlin/Heidelberg, Germany, 2008; pp. 21-54.

24. Akpan, E.B.; Farrow, G.E.; Morris, N. Limpet grazing on Cretaceous algal-bored ammonites. Palaeontology 1982, 25, 361-367.

25. Bromley, R.G. A stratigraphy of marine bioerosion. In The Application of Ichnology to Palaeoenvironmental and Stratigraphic Analysis; McIlroy, D., Ed.; Geol. Soc. Spec. Pub.: London, UK, 2004; pp. 455-479.

26. Smolarek, J.; Trela, W.; Bond, D.P.G.; Marynowski, L. Lower Wenlock black shales in the northern Holy Cross Mountains, Poland: Sedimentary and geochemical controls on the Ireviken Event in a deep marine setting. Geol. Mag. 2017, 154, 247-264. [CrossRef]

27. Boulesteix, K.; Poyatos-More, M.; Flint, S.S.; Taylor, K.G.; Hodgson, D.M.; Hasiotis, S.T. Transport and deposition of mud in deep water environment: Processes and stratigraphic implications. Sedimentology 2019, 66, 2894-2925. [CrossRef]

28. Stow, D.A.V.; Faugères, J.-C.; Howe, J.A.; Pudsey, C.J.; Viana, A.R. Bottom currents, contourites and deep-sea sediment drifts: Current state-of-the-art. Geol. Soc. Lond. Mem. 2002, 22, 7-20. [CrossRef] 
29. Esentia, I.P. Morphostructure and Tectono-Sedimentary Control of a Mixed Contourite-Turbidite System in a Transpressive Margin: Gulf of Cadiz, SW Iberia. Ph.D. Thesis, Heriot-Watt University, Edinburgh, UK, 2020.

30. Bankole, S.A. Methods, Microstructure and Mudrocks: Towards an Improved Understanding of Deep-Water Mudrocks. Ph.D. Thesis, Heriot-Watt University, Edinburgh, UK, 2018.

(C) 2020 by the authors. Licensee MDPI, Basel, Switzerland. This article is an open access article distributed under the terms and conditions of the Creative Commons Attribution (CC BY) license (http://creativecommons.org/licenses/by/4.0/). 